Jurdimas (Jurnal Pengabdian Kepada Masyarakat) Royal

Vol. 4 No. 3, September 2021, hlm. 211 - 216

ISSN 2614-7912 (Print)

DOI: https://doi.org/10.33330/jurdimas.v4i3.860

ISSN 2622-3813 (Online)

Available online at https://jurnal.stmikroyal.ac.id/index.php/jurdimas

\title{
PELATIHAN BLENDED LEARNING PADA GURU SMA KATOLIK 1 KABANJAHE
}

\author{
Sanjaya Pinem $^{1^{*}}$, Viktor Edison Hutagaol ${ }^{2}$ \\ ${ }^{1}$ Program Studi Penerbitan, Politeknik Negeri Media Kreatif \\ ${ }^{2}$ Program Studi Teknik Lingkungan, Universitas Efarina \\ email: *pinemsanjaya@gmail.com
}

\begin{abstract}
Technology information using the internet can benefit educators and provide information to students to transfer knowledge has a very high potential. The purposes of these community service are: (1) to expand the insight, knowledge, and experience directly about the model of blended learning for teachers, especially teachers of Sma Katolik 1 Kabanjahe; (2) Teachers can use elearning moodle learning technology. The techniques that are planned to shape the motivation and participation of educators ranging from the benefits of blended learning, and the application of blended learning so that educators in directly implementing it in the classroom. The implementation method starts in a structured manner starting from the initial discussion about blended learning, taking the results of the initial questionnaire, then giving independent tasks to the teachers. This community service was attended by 12 teachers at SMA Katolik 1 Kabanjahe, Kab. Karo. North Sumatra. The important conclusion of this community service is the awareness and ability of educators in using information technology, especially blended learning can increase motivation to educators to provide maximum learning to learners.
\end{abstract}

Keywords: blended learning; moodle; teaching technology

\begin{abstract}
Abstrak: Teknologi informasi dengan menggunakan internet dapat menguntungkan para pendidik dalam memberikan informasi kepada peserta didik. Pengetahuan tentang teknologi informasi mempunyai potensi yang sangat tinggi. Tujuan dari penulisan: (1) memperluas wawasan, pengetahuan dan pengalaman secara langsung tentang model pembelajaran blended learning untuk guru guru khususnya Guru SMA Katolik 1 Kabanjahe; (2) Guru-guru dapat menggunakan teknologi pembelajaran elearning moodle. Teknik yang direncanakan untuk membentuk motivasi dan partisipasi tenaga pendidik mulai dari keuntungan blended learning, dan pengaplikasian blended learning sehingga tenaga pendidik dalam langsung mengimplementasikannya di dalam kelas. Metode pelaksanaan dimulai secara terstruktur mulai dari diskusi awal tentang blended learning, mengambil hasil kuesioner awal, selanjutnya memberikan tugas mandiri kepada guru-guru. Pelaksanaan pengabdian kepada masyarakat ini diikuti oleh 12 guru di SMA Katolik 1 Kabanjahe, kab. Karo. Sumatera Utara. Kesimpulan penting dari pengabdian ini adalah adanya kesadaran dan kemampuan pendidik dalam menggunakan teknologi informasi khususnya blended learning dapat meningkatkan motivasi kepada tenaga pendidik untuk memberikan pembelajaran yang maksimal kepada peserta didik.
\end{abstract}

Kata kunci: blended learning; moodle; teknologi pembelajaran 
Available online at https://jurnal.stmikroyal.ac.id/index.php/jurdimas

\section{PENDAHULUAN}

Teknologi Informasi yang terupdate dapa memberikan manfaat bagi dunia pendidikan dan harus dirancang secara baik dan terorganisir (Wijaya, Sudjimat, \& Nyoto, 2016). Meskipun demikian, teknologi informasi harus disertai dengan pengetahuan pengguna yang baik sehingga teknologi informasi tersebut dapat memberikan dampak yang sangat menguntungkan bagi pihak- pihak yang menggunakannya. Salah satu media teknologi informasi adalah media komputer dengan mengunakan internet (Marhendra, Suryaningtiyas, \& Kristanti, 2016). Teknologi informasi juga mampu yang menjadi media pembelajaran memung-kinkan peserta didik untuk belajarsecara mandiri tanpa harus hadirnya seorang guru sehingga memunculkan belajar dengan menggunakan elearning (Thomas \& Setiaji, 2014).

Kehadiran elearning sebagai salah satu media pembelajaran dalam jaringan (daring) memberikan tenaga baru bagi tenaga pendidik sebagai cara untuk memberikan materi kepada peserta didik. Suasana pembelajaran dengan menggunakan teknik dalam jaringan (daring) memaksa tenaga pendidik untuk membuat pembelajaran sekreatif mungkin serta aktif dalam jaringan (daring) sehingga peserta didik antusias dalam mengikuti pembelajaran daring.

Salah satu jenis elearning adalah blended learning dan di SMA Katolik 1 Kabanjahe masih belum efektif, sehingga dibutuhkan rencana agar dapat meningkatkan hasil belajar peserta didik sehingga tujuan pembelajaran dapat tercapai. Hal tersebut dikuatkan dengan hasil kuesioner awal tentang pengetahuan awal guru-guru SMA Katolik 1 Kabanjahe.
Sebagai salah satu SMA unggul di Kota Kabanjahe dengan konektifitas internet yang sudah memadai karena berada di tengah kota sudah seharusnya pengetahuan guru-guru SMA Katolik 1 Kabanjahe akan media pembelajaran dalam jaringan (daring) mengetahui teknik dan cara menggunakan pembelajaran elearning dengan model blended learning (Batubara, 2018). Maka dari itu guruguru SMA Katolik 1 Kabanjahe perlu metode pengajaran dengan menggunakan elearning model blended learning untuk meningkatan pengetahuan dan keterampilan guru- guru di sekolah tersebut sehingga pembelajaran kepada peserta didik dapat di optimalkan (Fauziah, 2011). Untuk mendukung tujuan dari metode ini maka dilakukan pelatihan guru-guru di SMA Katolik 1 Kabanjahe dalam menerapkan model blended learning sehingga mereka memiliki kemampuan dalam meng-aplikasikan blended learning dalam pembelajaran secara maksimal (Nugraha, Sellyana, \& Suhaidi, 2019). Pelatihan ini memungkinkan peserta pelatihan dapat menyerap ilmu pengetahuan secara optimal meskipun menggunakan media dalam jaringan (Sjukur, 2013).

Pernahkah Anda Menggunakan Metode Pembelajaran 12 responses

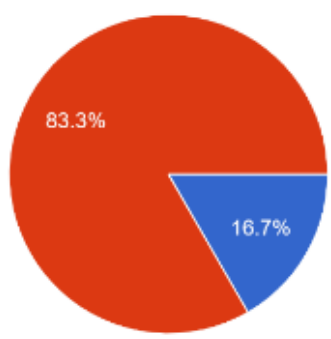

Gambar 1. Kuesioner Awal 
Available online at https://jurnal.stmikroyal.ac.id/index.php/jurdimas

\section{METODE}

Metode pemecahan masalah atas permasalahan tersebut, diantaranya adalah dengan pelatihan model blended learning guru-guru di SMA Katolik 1 Kabanjahe, dapat diketahui tingkat kemampuan dan pemahaman guru-guru terhadapat teknik dan penggunaan blended learning dalam proses pembelajaran yang baik dan benar.

Metode pemecahan masalah pelatihan terbagi atas delapan (8) sub metode yang berkesinambungan dapat dilihat pada tabel 1. Evaluasi dalam pelatihan ini dilakukan dalam dua jenis yaitu yang pertama adalah Kuisioner Awal (Survey) yang diberikan kepada guru-guru untuk mengetahui kemampuan sekarang sewaktu diadakan survey terutama untuk pengetahuan tentang blended learning dalam hal ini pengetahuan tentang moodle, atau blended learning secara umum. Kedua adalah Evaluasi Akhir (Post-test) yang dilakukan untuk mengetahui kemampuan guru-guru setelah dilakukan pelatihan blended learning. Evaluasi ini terbagi atas dua jenis yaitu dari sisi kemampuan guru untuk membuat materi ajar (course) dan melengkapinya, dan evaluasi tentang proses penyampaian materi atau isi dari moodle kepada peserta didik.

Acuan indikator keberhasilan dari pelatihan ini dilihat dari adanya pemahaman peserta tentang adanya model pembelajaran blended learning dengan menggunakan moodle. Kedua peserta pelatihan (guru-guru) memiliki pengetahuan tentang software pembelajaran terutama yang open source (sumber terbuka), dan terakhir guruguru dapat melakukan manajemen moodle secara baik dan benar termasuk upload materi sesuai dengan mata pelajaran yang diampu yang efektif dan efisien.

\section{Faktor Pendukung Pelatihan}

Adanya faktor pendudukung dari pelatihan ini membuat pelatihan dapat berjalan dengan lancar yang diantaranya adalah lokasi Sekolah SMA Katolik 1 Kabanjahe dekat dengan kota, sehingga akses internet sudah cukup memadai untuk menggunakan teknologi pembelajaran dengan model blended learning. Serta motivasi para peserta dalam mengikuti pelatihan dari awal pelatihan hingga berakhirnya pelatihan didukung oleh pengetahuan dasar komputer yang cukup tinggi.

\section{Faktor Penghambat Pelatihan}

Faktor yang membuat pelatihan ini dapat menjadi kendala adalah kebanyakan guru belum mempunyai bahan ajar digital sehingga, materi yang dibuat harus dipersiapkan terlebih dahulu dan juga komputer dan laptop dalam tempat pelatihan sangat terbatas, sehingga workshop menggunakan alternative handphone pintar, dan pembagian komputer dan laptop digunakan oleh 2 atau 3 orang dalam 1 laptop. Dan tindak evaluasi dalam tugas mandiri, kecepatan guru-guru untuk menyelesaikan tugas mandiri tersebut bervariasi sehingga pendampingan pribadi memakan waktu yang cukup banyak, dan diperlukan pelatihan intensif bagi peserta pelatihan. 
Tabel 1. Metode Kegiatan Pelaksanaan Pengabdian

\begin{tabular}{|c|c|c|}
\hline No & Materi & Metode Kegiatan \\
\hline 1 & $\begin{array}{l}\text { Pengantar tentang sistem pembelajaran dengan } \\
\text { blended learning }\end{array}$ & Ceramah, diskusi \\
\hline 2 & Pemahaman blended learning & Ceramah, diskusi \\
\hline 3 & Kuisioner Awal & Tes Individu \\
\hline 4 & Install Moodle sebagai aplikasi Blended learning & Tutorial \\
\hline 5 & Manajemen Moodle sebagai Guru & Tutorial \\
\hline 6 & Review Materi & Tugas \\
\hline 7 & $\begin{array}{l}\text { Tugas Mandiri: Pembuatan manajemen content pada } \\
\text { moodle termasuk pengaturan materi ajar dan } \\
\text { pengunggahan materi ajar }\end{array}$ & Tugas \\
\hline 8 & Pendampingan bagi yang memerlukan konsultasi & Diskusi, tanya jawab \\
\hline
\end{tabular}

\section{PEMBAHASAN}

Secara garis besar pelatihan blended learning dengan pengembangan menggunakan moodle berlangsung lancar dan sangat baik, karena telah sesuai sesuai dengan rencana proposal yang telah ditetapkan terlebih dahulu. Dari jumlah total peserta pelatihan sebanyak 12 orang, tersebar dari beberapa pengampu mata pelajaran di SMA Katolik 1 Kabanjahe.

Tingkat kehadiran peserta pelatihan selama dua hari juga menunjukkan hasil yang cukup bagus karena 98\% dari peserta hadir dan mengikuti pelatihan setiap harinya. Dalam proses pelatihan ini, setiap peserta dapat mengakses moodle di server yang sudah disediakan panitia setelah diberikan pengarahan dan tata cara penginstallan moodle di komputer guru. Sehingga guru-guru peserta pelatihan dapat belajar sambil praktek langsung (learning by doing). Penyampaian materi diberikan kepada peserta pelatihan dengan menggunakan cara diskusi dan ceramah dan diberikan tutorial step by step.
Pada tahap evaluasi diberlakukan tugas mandiri yang diberikan kepada guru-guru untuk membuat konten elearning mereka sendiri didalam sistem moodle yang sesuai dengan mata pelajaran diampu di SMA Katolik 1 Kabanjahe. Proses belajar sendiri/ mandiri, peserta pelatihan dibantu oleh panitia untuk memaksimalkan potensi guru dalam penggunaan model pembelajaran model blended learning, sehingga dalam akhirnya kemampuan guru untuk menyelesaikan tugas mandiri ini akan menjadi acuan apakah peserta sudah mempunyai kompetensi atau kemampuan yang diajarkan saat pelatihan. Dari hasil yang didapatkan dari tugas mandiri guru-guru SMA Katolik 1 Kabanjahe, hampir semuanya menyelesaikannya dengan baik. Waktu untuk menyelesaikan tugas mandiri bervariasi, ada yang cepat dan ada pula yang relatif lama.

Kegiatan pelatihan dalam kegiatan pengabdian masyarakat ini dideskripsikan dalam tiga poin penting, yang pertama adanya kegiatan diskusi awal dan persiapan pelaksanan pengabdian yang berupa kegiatan 
kunjungan ke sekolah mitra untuk membicarakan beberapa hal teknis terkait pelaksanaan pelatihan blended learning dengan moodle bagi guru SMA KATOLIK 1 Kabanjahe serta penerapannya.

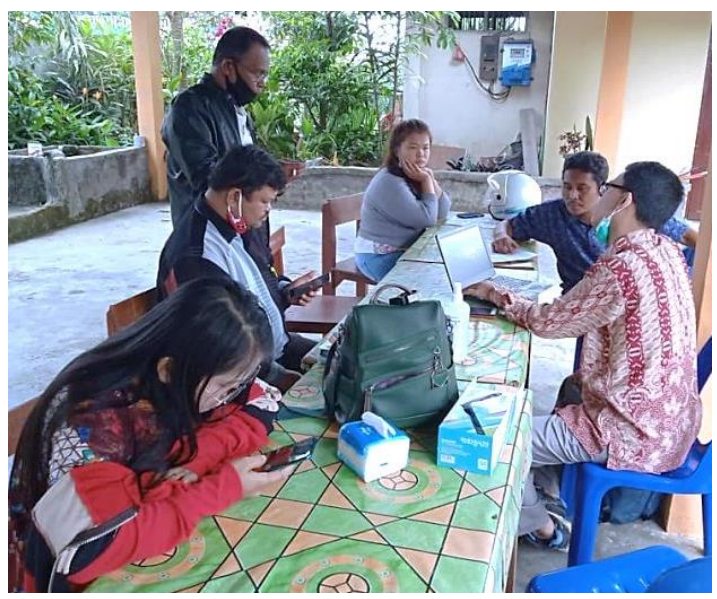

Gambar 2. Diskusi pelatihan dasar blended learning

poin kedua inti dari pelatihan ini yaitu, praktek langsung model pembelajaran blended learning dengan moodle dengan untuk memberikan pengenalan kepada mitra guru-guru mengenai manfaat dan kelebihan blended learning untuk meningkatkan kompetensi guru sehingga pengetahuan guru akan perkembangan teknologi informasi khususnya dibidang Pendidikan dapat lebih meningkat.

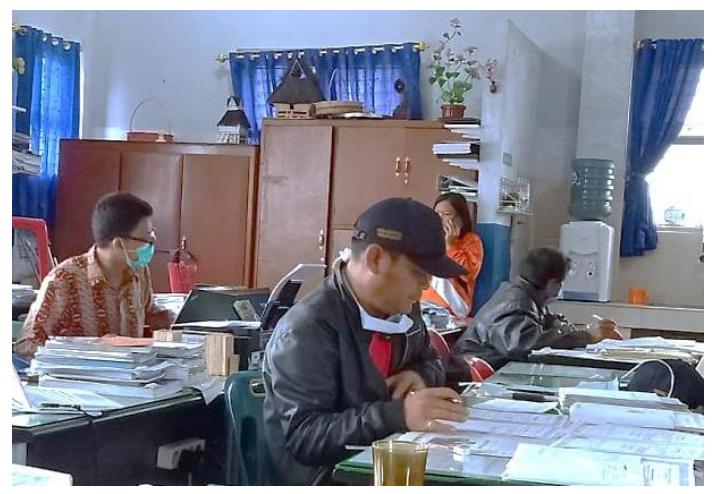

Gambar 2. Praktek langsung model pembelajaran blended lerning poin yang terakhir adalah pembangunan dan instalasi webserver xampp sebagai server moodle sebagai wadah untuk software moodle bekerja, sehingga peserta pelatihan dapat menerapkan ilmu yang didapat dari pelatihan ini secara langsung.

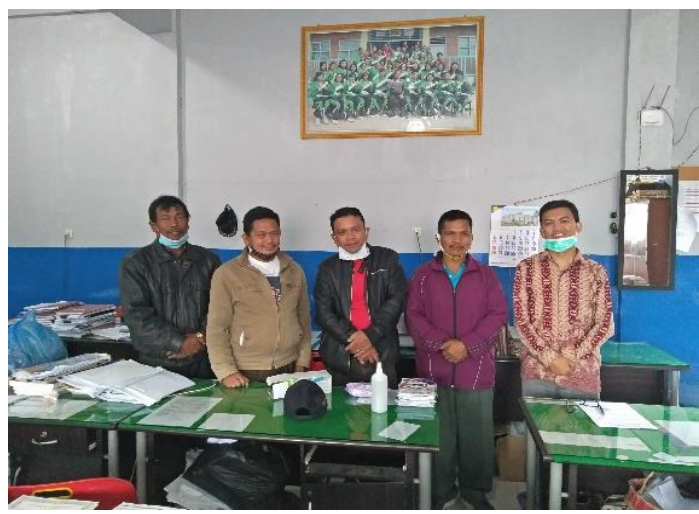

Gambar 2. Berfoto bersama setelah selesai pelatihan

\section{SIMPULAN}

Setelah dilakukan pelatihan blended learning dengan menggunakan moodle yang tepat sasaran, karena sebelum adanya pelatihan tenaga pendidik belum mempunyai kemampuan untuk mengelola aplikasi blended learning dengan menggunakan moodle, dan sewaktu pelatihan motivasi para pendidik menjadi sangat tinggi, hal itu ditunjukkan dari tingkat prosentase kehadiran peserta pelatihan hampir mencapai $99 \%$ sehingga menunjukkan antusiasme guru-guru dalam mengikuti pelatihan model pembelajaran blended learning. Diakhir pelatihan tenaga pendidik sudah mampu mengelola dan mengoperasikan moodle mulai dari mendaftarkan siswa, mengisi materi, memberi kuis, dan cara mengevaluasi hasil kerja siswa.

\section{DAFTAR PUSTAKA}


Batubara, H. H. (2018). Pengembangan Situs E-Learning Dengan Moodle Versi 3.1 Sebagai Media Pembelajaran Pada Program Studi Pendidikan Guru Madrasah Ibtidaiyah. AlBidayah: Jurnal Pendidikan Dasar Islam. doi: 10.14421/albidayah.v9i1.116

Fauziah, Y. N. (2011). Analisis Kemampuan Guru Dalam Mengembangkan Keterampilan Berpikir Kreatif Siswa Sekolah Dasar Kelas V Pada Pembelajaran Ilmu Pengetahuan Alam. Edisi Khusus.

Handoko, W., Iqbal, M., \& Efendi, Z. (2020). Pelatihan Penerapan Simulah 1.0 Berbasis Web Bagi Guru SMK Negeri 1 Kisaran. Jurdimas (Jurnal Pengabdian Kepada Masyarakat) Royal, 3(2), 135140.doi:10.33330/jurdimas.v3i 2.485

Marhendra, A. G., Suryaningtiyas, W., \& Kristanti, F. (2016). Penggunaan Model Pembelajaran Blended Learning terhadap Hasil Belajar Matematika Kelas VIII di SMPN 38 Surabaya. MUST: Journal of Mathematics Education, Science and Technology. doi: 10.30651/must.v1i1.97

Nugraha, N. B., Sellyana, A., \& Suhaidi, M. (2019). Pelatihan ELearning Pada Guru Sma It Plus Bazma Brilliant. 2(2), 127-132.

Sjukur, S. B. (2013). Pengaruh blended learning terhadap motivasi belajar dan hasil belajar siswa di tingkat SMK. Jurnal Pendidikan Vokasi. doi: 10.21831/jpv.v2i3.1043

Thomas, P., \& Setiaji, K. (2014). ELearning Dengan Pendekatan Kooperatif Tipe Jigsaw Untuk Meningkatkan Aktivitas Dan Hasil Belajar Mahasiswa. Dinamika Pendidikan Unnes, 9(1). doi: 10.15294/dp.v9i1.3353

Wijaya, E. Y., Sudjimat, D. A., \& Nyoto, A. (2016). Transformasi Pendidikan Abad 21 Sebagai Tuntutan Pengembangan Sumber Daya Manusia di Era Global. Prosiding Seminar Nasional Pendidikan Matematika.

Yuliasari, U., \& Permata, R. D. (2021). Pelatihan Pembuatan Media Pembelajaran Kiddy Learning Binder Bagi Guru Paud. Jurdimas (Jurnal Pengabdian Kepada Masyarakat) Royal, 4(1), 7-12. doi:10.33330/jurdimas.v4i1.91 5 . 